\title{
Drużyna Solidarności. Jak wybierano kandydatów na posłów i senatorów, czyli późniejszych członków Obywatel- skiego Klubu Parlamentarnego
}

\section{GRZEGORZ MAJCHRZAK}

Instytut Pamięci Narodowej ORCID: 0000-0002-9267-7769
W wyborach parlamentarnych z 4 czerwca 1989 roku strona solidarnościowa, a dokładnie jej część reprezentowana przez Komitet Obywatelski „Solidarność", osiągnęła sukces, którego się absolutnie nie spodziewała, który zaskoczył nawet jej działaczy. Udało się jej zdobyć niemal wszystkie - możliwe do zdobycia - miejsca w sejmie, ponad 90\% miejsc w senacie. W drugiej turze, która odbyła się dwa tygodnie później - 18 czerwca - wywalczyła ostatnie brakujące miejsce w sejmie (Andrzej Wybrański), a także siedem z ośmiu w senacie (Henryk Grządzielski, Stanisław Hoffmann, Cezary Józefiak, Jan Józef Lipski, Zdzisław Nowicki, Aleksander Paszyński i Antoni Żurawski) ${ }^{1}$. W efekcie posłami zostało 161 jej kandydatów, a senatorami kolejnych 99. Pozwalało to na stworzenie drugiego co do wielkości (oczywiście po Polskiej Zjednoczonej Partii Robotniczej) klubu parlamentarnego. Było to efektem strategii przyjętej przed wyborami, obliczonej na zdobycie maksymalnej liczby mandatów. De facto oznaczało to, że przyszłych posłów i senatorów Obywatelskiego Klubu Parlamentarnego wyłoniono nie w wyborach czerwcowych (oczywiście bez umniejszania ich rangi i znaczenia), ale kilka tygodni wcześniej - już w trakcie układania list wyborczych. Nikt się zresztą nie spodziewał, że te swoiste prawybory tak naprawdę - wobec plebiscytowego charakteru wyborów z czerwca 1989 roku - wyłonią przyszłych parlamentarzystów². Dlatego też warto temu procesowi przyjrzeć się szczególnie dokładnie.

Pod koniec marca 1989 roku przywódcy Komitetu Obywatelskiego przy Przewodniczącym NSZZ "Solidarność" (byli wśród nich oprócz samego Lecha Wałęsy również Bogdan Borusewicz, Bronisław Geremek, Jacek Kuroń, Bogdan Lis, Janusz Pałubicki, Grażyna Staniszewska, Antoni Stawikowski, Andrzej Wielowieyski oraz Henryk Wujec)

1. Jedynym senatorem spoza listy Komitetu Obywatelskiego został Henryk Stokłosa, który otrzymał 49,5\% ważnych głosów. Wygrał on z Piotrem Baumgartem. Co więcej, ten ostatni przegrał również z wojewodą pilskim Zbigniewem Rosińskim - otrzymał on 43,3\% głosów, podczas gdy Baumgart 42,6\% (A. Dudek, Reglamentowana rewolucja. Rozkład dyktatury komunistycznej w Polsce 1988-1990, Kraków 2004, s. 329). Z ramienia Komitetu Obywatelskiego senatorem z województwa pilskiego został natomiast (w drugiej turze) Zdzisław Nowicki, który uzyskał 50,09\% głosów (Nasi w Sejmie i Senacie. Posłowie i senatorowie wybrani z listy Solidarności", Warszawa 1990, s. 239).

2. Warto w tym miejscu przypomnieć, że tego niespodziewanego sukcesu zapewne nie osiągnięto by bez wsparcia (także materialnego) dziesiątek tysięcy osób, które społecznie zaangażowały się w kampanię komitetów obywatelskich. 
uzgodnili utworzenie regionalnych sztabów wyborczych, których zadaniem miało być między innymi wytypowanie kandydatów do parlamentu oraz sporządzenie regionalnych list do sejmu i senatu. Całość działań miał z kolei koordynować centralny sztab wyborczy, a akcję wyborczą firmować Komitet Obywatelski. Zadecydowano również, że nie należy dopuścić do tego, aby działacze Solidarności byli wysuwani przez inne organizacje lub by z ramienia związku kandydowały osoby niemające akceptacji K0 i Lecha Wałęsy. Wstępnie opowiedziano się także za centralizacją w sprawie kandydatów na miejsca do obsadzenia, co oznaczało ustalenie jednej, popieranej w każdym okręgu listy ${ }^{3}$. Wycofanie się z pomysłu wolnej konkurencji wyborczej - lansowanej przez stronę opozycyjną przy 0krągłym Stole na rzecz jednej listy opozycyjnej w każdym okręgu - było uzasadniane bliskim terminem wyborów, a także ogromną dysproporcją sił pomiędzy władzami PRL a Solidarnością ${ }^{4}$.

W kwietniu 1989 roku formalną uchwałę w sprawie wyborów do sejmu i senatu przyjęła Krajowa Komisja Wykonawcza NSZZ "Solidarność". Zobligowała ona Komitet Obywatelski przy Przewodniczącym NSZZ "Solidarność" Lechu Wałęsie "do objęcia patronatu" nad kampanią wyborczą, jako Komitet Obywatelski „Solidarność". Jednocześnie zalecała regionalnym strukturom związku zorganizowanie (we współpracy z NSZZ Rolników Indywidualnych) wojewódzkich czy regionalnych Komitetów Obywatelskich "Solidarność". I to właś- nie ich zadaniem miało być "formowanie regionalnych list kandydatów", wystawianie przedstawicieli do komisji wyborczych oraz prowadzenie kampanii wyborczej. Na podstawie tych zestawień regionalnych zbiorczą listę krajową miał z kolei opracować Komitet Obywatelski "Solidarność". Powinien on uzyskać "pełne poparcie" Solidarności oraz jej przewodniczącego $0^{5}$. Jednocześnie Krajowa Komisja Wykonawcza „wyrażała nadzieję", że na listach tych znajdą się "osoby reprezentujące różne środowiska społeczne i różne orientacje polityczne kontynuujące solidarnościową tradycję odpowiedzialności za losy ludzi pracy w Polsce i za losy kraju", a wśród nich również członkowie Związku. Co prawda KKW nie stwierdzała tego w swej uchwale wprost, ale de facto zaakceptowała zasadę "jeden kandydat (jedna kandydatka) na jedno miejsce" - tak należy bowiem rozumieć stwierdzenie 0 „zbiorczej liście krajowej kandydatów na wszystkie dostępne mandaty"6.

W dzień po uchwale Krajowej Komisji Wykonawczej NSZZ "Solidarność", 8 kwietnia 1989 roku zebrał się Komitet Obywatelski „Solidarność", który ostatecznie przesądził tryb wyłaniania kandydatów na parlamentarzystów, a także podjął decyzję o utworzeniu w K0 zespołów, których zadaniem będzie przygotowanie wyborów, a także wyraził - jak stwierdzał, zgodnie $\mathrm{z}$ wnioskiem przewodniczącego Lecha Wałęsy i KKW - "gotowość objęcia patronatu" nad kampanią wyborczą do sejmu i senatu . Wśród tych zespołów znalazł się między innymi zespół ds. koordynacji listy kandydatów ${ }^{8}$.

3. A. Friszke, Geneza i historia Komitetu Obywatelskiego, [w:] Komitet Obywatelski przy Przewodniczacym NSZZ "Solidarność" Lechu Wałęsie. Stenogramy posiedzeń 7 listopada 1987, 18 grudnia 1988, 23 kwietnia 1989, oprac. M. Strasz, Warszawa 2006, s. 58-59.

4. Ibidem, s. 59.

5. Uchwała Krajowej Komisji Wykonawczej NSZZ "Solidarność" z dnia 7 kwietnia 1989 r. w sprawie wyborów do Sejmu i Senatu, [w:] Dokumenty władz NSZZ „Solidarność" 1981-1989, oprac. J. Olaszek, Warszawa 2010, s. 339.

6. Ibidem.

7. W uchwale Komitetu Obywatelskiego stwierdzano między innymi: „Komitet Obywatelski uformowany jako K0 «Solidarność» na podstawie list regionalnych przedstawionych przez powołane zgodnie z uchwałą KKW regionalne lub wojewódzkie Komitety Obywatelskie «Solidarność» utworzy listę kandydatów opozycyjno-solidarnościowych w skali krajowej na wszystkie dostępne w wyborach mandaty". I dodawano: "Komitet Obywatelski z zadowoleniem przyjmuje fakt, że «Solidarność» i jej Przewodniczący liście tej udzielą pełnego poparcia” (Dokumenty Komitetu Obywatelskiego. Uchwała, "Tygodnik Mazowsze” 1989, nr 290, s. 1).

8. W jego skład weszli: Piotr Baumgart, Zbigniew Bujak, Władysław Frasyniuk, Bronisław Geremek, Jerzy Kłoczowski, Marian Krzaklewski, Aleksander Paszyński, Zbigniew Rokicki, Henryk Samsonowicz, Józef Ślisz, Andrzej Stelmachowski, Stanisław Stomma i Michał Żórawski, przy czym - jak stwierdzano - był on "otwarty do uzupełnienia na drodze kooptacji” (ibidem). 
Proces wyłaniania kandydatów na posłów i senatorów na szczeblu wojewódzkim najczęściej przebiegał w sposób demokratyczny. W większości komitetów obywatelskich odbywały się prawybory przeprowadzane według ustalonych uprzednio demokratycznych procedur i przyjętych regulaminów, a samo głosowanie niejednokrotnie miało charakter tajny i składało się z kilku tur ${ }^{9}$. Tak było na przykład na Górnym Śląsku, gdzie przeprowadzono trzy rundy ${ }^{10}$. 0czywiście w poszczególnych przypadkach ten tryb się różnił, niekiedy znacząco. Na przykład w Olsztynie przeprowadzono wstępny, wewnętrzny sondaż, na którego podstawie 19 kwietnia przygotowano listę kandydatów, uszeregowaną według liczby uzyskanych przez nich głosów. Była ona omawiana dzień później podczas posiedzenia Komitetu Obywatelskiego Regionu Warmińsko-Mazurskiego i w "długotrwałej i miejscami bardzo burzliwej dyskusji oraz [przy] licznych wnioskach" ustalono listę osób, które miały zaprezentować swój program. Przy czym przychylono się do wniosku Ireny Telesz, aby osoby, które uzyskały w sondażu tylko jeden głos, zrezygnowały $z$ dalszego kandydowania. Jednocześnie odrzucono propozycję, aby jednym z kandydatów był proponowany przez Warszawę Andrzej Wielowieyski. Ostatecznie więc na liście znalazło się sześć osób, z których pięć zaprezentowało swoje osiągnięcia zawodowe i społeczne (w tym oczywiście działalność związkową) oraz programy. Odpowiadały one również na liczne pytania. Podczas tej prezentacji nieobecny był Zenon Złakowski (jego list odczytał Stefan Kurowski, który wyjaśnił też powód jego absencji), co nie przeszkodziło mu zresztą w wyborze na kandydata Komitetu Obywatelskiego Regionu Warmińsko-Mazurskiego do sejmu. Oprócz niego wybrano również Antoniego Jutrzenkę-Trzebiatowskiego i Erwina Kruka (obaj kandydowali do senatu) oraz Grażynę Langowską i Józefa Lubienieckiego (wybory do sejmu) ${ }^{11}$.

Wyłanianie kandydatów na posłów i senatorów miało niekiedy dość burzliwy przebieg. Tak było między innymi w stolicy Dolnego Śląska. Już w chwili rozpoczęcia zgłaszania kandydatów doszło tam do pierwszego ostrego sporu w gronie reprezentantów wsi. W związku z tym, że nie byli oni w stanie uzgodnić na sali obrad jednego, wspólnego kandydata, szef wrocławskiego Komitetu Obywatelskiego "Solidarność" Adolf Juzwenko poprosił ich o wyjście do pokoju obok i dokonanie tam wyboru w węższym, własnym gronie. Leszek Budrewicz wspominał potem: „podczas wyborów kłócili się, nie mogli dojść do porozumienia, jedni podważali wiarygodność drugich. Następnie zrobiono przerwę, dano im 15 minut - wyszli do innego pokoju, gdzie doszło do wielkiej awantury, słychać było podniesione głosy, czekaliśmy, aż zaczną łamać krzesła. Wyszli jednak spokojnie, w milczeniu, z ustalonym kandydatem. Był nim Zbigniew Lech, który wprawdzie później w polityce się wyróżnił, ale wielkim mówcą nie był"12. Nie obniżyło to jednak bynajmniej temperatury spotkania. Ewa Unger z Klubu Inteligencji Katolickiej poinformowała zgromadzanych działaczy K0, że do KIK napływały prośby "0 jakiegoś ekologa i o Antoniego Lenkiewicza"13.

9. I. Słodkowska, Komitety Obywatelskie 1989-1992. Rdzeń polskiej transformacji, Warszawa 2014, s. 88. Podobnie jak na Górnym Śląsku było również "w innych województwach" (ibidem).

10. Posiedzenia Komitetu Obywatelskiego „Solidarność”, 23 kwietnia 1989 roku, Audytorium Maximum Uniwersytetu Warszawskiego, [w:] Komitet Obywatelski przy Przewodniczacym..., s. 259.

11. R. Gieszczyńska, Komitet Obywatelski "Solidarność" Regionu Warmińsko-Mazurskiego w wyborach 4 czerwca 1989 roku, [w:] Olsztyński Czerwiec '89, Olsztyn 2009, s. 19-20. Jak stwierdza Renata Gieszczyńska, ta procedura wynikała z tego, że działacze K0 „poszukiwali takiego rozwiązania wyłonienia kandydatów, które pozwoliłoby na włączenie jak największej grupy osób reprezentujących środowiska opozycyjne z całego województwa w tak krótkim czasie”, a przy tym "uwzględniając specyfikę regionu, podkreślali konieczność dotarcia do mieszkańców wsi, a także do mniejszości narodowych i wyznaniowych, ze szczególnym uwzględnieniem Warmiaków i Mazurów" (ibidem, s. 20).

12. S. Ligarski, Komitet Obywatelski NSZZ "Solidarność" we Wrocławiu, t. 1, s. 15 (maszynopis w posiadaniu autora).

13. Ibidem. 
Propozycje i uwagi zgłaszano również telefonicznie. W ten właśnie sposób zgłoszono zastrzeżenia wobec kandydatury Barbary Labudy. Jarosław Obremski wspominał Pawłowi Kowalskiemu: „Próbowaliśmy jakoś spowodować, żeby jakoś nie Basia, bo Basia była na pewno kontrowersyjną osobą. Profesura też była przeciwko Labudzie, ale jak przyszło do głosowania, to na apel Frasyniuka, nie mieli śmiałości zagłosować przeciw, więc my wtedy głosowaliśmy blokiem przeciwko. I Basia chyba z minimalną ilością głosów wygrała z Grażyną Tomaszewską"14.

W związku z narastającymi podziałami oraz wątpliwościami wobec kandydatur do sejmu (do senatu bez większych problemów zatwierdzono Romana Dudę i Karola Modzelewskiego) Barbara Trzeciak-Pietkiewicz "zaapelowała do obecnych na sali aby uwolnić się od podziałów środowiskowych i poprosiła aby postawić na wyrobienie polityczne i siłę przebicia"15. W związku z tym przewodniczący Komitetu Obywatelskiego Adolf Juzwenko zaproponował, aby wybierając kandydatów, kierować się następującymi kryteriami: „nośność nazwiska, doświadczenie polityczne, potencjał intelektualny, mobilność, reprezentatywność środowiska, kontrowersyjność w społeczeństwie, umiejętność bycia sobą" ${ }^{16}$. Z kolei Romuald Siepsiak przytomnie zwrócił się do zebranych, aby decyzje w sprawie kandydatur zapadły na tym spotkaniu, , bo do następnego spotkania pojawią się następne kandydatury i kłopot będzie jeszcze większy"17. Atmosfera spotkania i narastające spory zaczęły zresztą budzić obawy również innych jego uczestników, szczególnie Franciszka Połomskiego i Józefa Łukaszewicza, którzy chcieli, aby komitet zaczął głosować nad wszystkimi kandydaturami. Łukaszewicz bowiem - jak twierdził - zauważył "presję na wycofanie się kandydatów"18. Z kolei Władysław Frasyniuk sprzeciwił się przesłuchiwaniu kandydatów, argumentując, że ono "niewiele da, bowiem każdy będzie mógł się do takiego wystąpienia przygotować ${ }^{\prime 19}$. Takie postawienie sprawy wywołało ripostę Ewy Unger, która "nie zgodziła się z przedmówcą stawiając głównie na wrażenie, jakie dany kandydat wywoła, elokwencję i zaapelowała, aby wybór kandydatów odłożyć" 20 . Ostatecznie jednak na tym posiedzeniu wybrano kandydatów nie tylko na senatorów, ale również na posłów, pozostawiając jedno miejsce wolne do rozstrzygnięcia przez samorząd pracowniczy. W rezerwie pozostawiono także kandydaturę Grażyny Tomaszewskiej, na wypadek gdyby ktoś ostatecznie zrezygnował ze startu w wyborach. Kandydatura ta wzbudzała zresztą sporo emocji, Tomaszewską utożsamiono bowiem ze środowiskiem radykalnej Solidarności Walczącej, przeciwnej jedynie częściowo demokratycznym wyborom ${ }^{21}$.

0czywiście proces wyłaniania kandydatów na posłów i senatorów przez komitety obywatelskie bacznie obserwowały władze PRL, na czele ze Służbą Bezpieczeństwa. I tak na przykład w jednym z raportów katowickiej SB z końca kwietnia 1989 roku stwierdzano, że ustalenie kandydatur "pogłębia antagonizmy wśród działaczy «S[olidarności]» w regionie". I dodawano: "Uwidacznia się to m.in. w częstych zmianach na liście kandydatów «S[olidarności]» na posłów oraz w negatywnych komentarzach poszczególnych osób w stosunku

14. Ibidem, s. 27.

15. Protokół z posiedzenia Komitetu Obywatelskiego "Solidarność" we Wrocławiu z dnia 17 kwietnia 1989 r., [w:] S. Ligarski, Komitet Obywatelski NSZZ "Solidarność"..., s. 67.

16. Ibidem, s. 68.

17. Ibidem, s. 70 .

18. Ibidem.

19. Ibidem.

20. Ibidem.

21. Na temat stosunku Solidarności Walczącej do wyborów czerwcowych zob. S. Ligarski, Rok 1989 a Solidarność Walcząca, [w:] Solidarność Walcząca 1982-1989. Studia i szkice, red. S. Ligarski, M. Siedziako, Szczecin-Warszawa 2019, s. 109-116. 
do wysuwanych kandydatów. Odrzucono kandydatury m.in. następujących znanych działaczy «Solidarności»: Tadeusza Jedynaka, członka Komisji Rewizyjnej RKW NSZZ «S[olidarność]», Kazimierza Świtonia, działacza Stronnictwa Pracy, członka RKW NSZZ «S[olidarność]». Osoby te ubiegają się o wybór na posła, prowadząc indywidualne kampanie wyborcze"22.

Czasem jednak zdarzały się odstępstwa od demokratycznej zasady wyłaniania kandydatów. Tak było na przykład w Warszawie. Jak wspomina przewodniczący stołecznego Komitetu Obywatelskiego Jan Lityński: „Początkowo myślałem, że kandydatów wyłonimy właśnie przez głosowanie w tym Komitecie, ale tutaj natrafiłem na dość duży upór $\mathrm{R}$ [egionalnej] K[omisji] W[ykonawczej], które miało ambicje, aby wyznaczać kandydatów na posłów, w uzgodnieniu z nami, ale... W rezultacie dziesięciu kandydatów na posłów zostało wyznaczonych przez

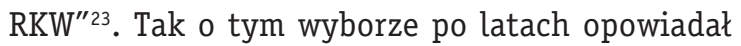
Jerzy Dyner, startujący w wyborach do sejmu: „To nie była kwestia jak w dzisiejszych czasach, że ktoś chce kandydować, to była kwestia wyboru władz związku. Nie dość tego, była to dość ostra selekcja jak na tamte czasy. Przypominam sobie doskonale spotkanie na Politechnice Warszawskiej, przed salą no chyba ok. 300-400 osób i to nie przypadkowych klientów, których tak jak dzisiaj można zbajerować byle opowieściami o świetlanej przyszłości Polski. Byli to starzy wyjadacze związkowi z ruchów różnych, wcześniejszych, którzy nie daliby się nabrać na byle opowieści, więc selekcja była bardzo merytoryczna. Poza tym dbano, jak pamiętam, o to żeby były reprezentowane poprzez «Solidarność» różne grupy zawodowe. Nie było tak, że jakieś grupy pominięto $\mathrm{z}$ definicji, były tam i wielkie zakłady pracy, czyli przemysł i było środowisko lekarzy, nauczycieli. Moją kandydaturę zgłosił Region Mazowsze"24.

Natomiast w przypadku izby wyższej parlamentu nie przeprowadzono żadnych prawyborów. Tak to opisuje ponownie Lityński: "Kandydatów na senatorów to już ja wybierałem. Głosowania żadnego nie było. Zwróciłem się do środowisk naukowych, do środowiska nauczycielskiego i do środowiska lekarskiego, żeby wyłonić tych kandydatów. Było dziewięciu kandydatów w dziewięciu dzielnicach Warszawy i trzech kandydatów zatwierdzonych przez to szerokie gremium Komitetu"25. Trudno powiedzieć, jak duży wpływ na wyłonienie kandydatów miał Lech Wałęsa, który zresztą przypisywał sobie w tej kwestii rolę decydującą. 20 maja 1989 roku podczas spotkania w Bydgoszczy mówił on w swoim stylu: „Jadę czołgiem «Solidarność» po zwycięstwo... Po prawdziwą wolność... po pluralizm... [...] Dopiero przyszłe wybory będą naprawdę wolne. Więc teraz twórzmy przyczółki, zdobywajmy teren. To jest właśnie zadanie wybranych przez mnie ludzi. Wybranych - przyznaję - nie zawsze demokratycznie. Nie było czasu na demokrację. Wziąłem odpowiedzialność za przyszłe wybory i doprowadzę do nich! Ale żeby do tego doprowadzić, muszę mieć lejce w rękach"26. Tak ważnej roli jednak nie odgrywał, choć z pewnością wpłynął - o czym będzie mowa dalej - na kształt list Komitetu Obywatelskiego. Na tym samym spotkaniu zresztą mówił dalej: „Niech zwycięży mądrzejszy, niech wygrywają lepsze rozwiązania. Tą drogą będę szedł, z tymi ludźmi, których wam proponuję, a przeciw innym, może równie wspaniałym, ale grającym indywidualnie, po partyzancku, a nie drużynowo [...]. Tam, gdzie będą demokratyczne wybory - proszę wybierzcie [Jana] Rulewskiego, ale wiedzcie, że tam, gdzie ja będę miał wybór, nie ma dla niego miejsca"27.

22. Cyt. za: P. Siedziako, Bez wyboru. Głosowania do Sejmu PRL (1952-1989), Warszawa 2018, s. 331.

23. Niespodzianka 1989, Warszawa 2010, s. 17-18.

24. Ibidem, s. 25.

25. Ibidem, s. 19.

26. P. Codogni, Wybory czerwcowe 1989 roku. U progu przemiany ustrojowej, Warszawa 2012, s. 130-131.

27. Ibidem, s. 31. Swą postawę wobec Rulewskiego uzasadniał krótko: „Bo kiedy potrzebowałem pomocy, kiedy byłem słaby, on nie pomógł mi. On mnie zdradził" (ibidem). 
Zdarzało się również, że Komitety Obywatelskie wyznaczały własne kryteria, które powinni spełniać kandydaci na przyszłych parlamentarzystów. Nieraz wymogi te były zresztą całkiem spore. Tak było na przykład w Bolesławcu, gdzie miejscowy Komitet Obywatelski 16 kwietnia 1989 roku zdecydował, że potencjalny kandydat (kandydatka): „1) Może, ale nie musi być członkiem «Solidarności»; bezpartyjny i bez przeszłości partyjnej. 2) Osoba otwarta na problemy innych ludzi, życzliwa i skłonna poświęcić im swoje umiejętności, czas i wiedzę. 3) Osoba o dużym poczuciu odpowiedzialności, o niezłomnej postawie trwania przy powszechnie uznanych za cenne wartościach. 4) Ktoś o zainteresowaniach szerszych niż zakreślone zawodem, zorientowany w podstawowych problemach miasta, Polski i świata. 5) Osoba mniej lub bardziej znana w środowisku i ceniona, z której postawą i poglądami mogą się utożsamiać nasze grupy społeczne. 6) Ktoś, kto głoszone ideały popiera czynem; kto podejmował lub sam uczestniczył w działaniach na rzecz ludzi «Solidarności», wspólnoty parafialnej, środowiska zawodowego". Jak przy tym dodawano: "Odstąpienie od jednego $z$ wyżej podanych kryteriów musi być uzasadnione szczególną wagą pozostałych"28.

Ustalanie list w taki sposób, aby zostały zaspokojone potrzeby i zachowany układ sił w terenie, ale również założenia przyjmowane centralnie, sprawiało oczywiście problemy. Mimo to odbywało się ono $\mathrm{w}$ tempie wręcz błyskawicznym. W ciągu nieco ponad dwóch tygodni od decyzji Krajowej Komisji Wykonawczej NSZZ "Solidarność", w niezwykle zresztą trudnych warunkach, zdecydowana większość kandydatów na parlamentarzystów została nie tylko wyłoniona w terenie, ale również zatwierdzona w centrali. Jak opisywał na podstawie przeprowadzonych jeszcze w 1989 roku badań socjolog Krzysztof Koseła: „Długo dyskutowano, kogo dopuścić do obrad mających zakończyć się wytypowaniem kandydatów, komu dać prawo głosu, a kogo trzymać za drzwiami sali obrad. Przy okazji wyszły na jaw podziały między aktywistami Solidarności, rywalizacja związku pracowniczego i chłopskiego, różnice zapatrywań działaczy Klubów Inteligencji Katolickiej i pozostałych osób, racje aktywistów godzących się na zasadę drużyny Lecha Wałęsy i tych, którzy mieli wątpliwości, co do tej zasady, wreszcie ważny konflikt pomiędzy działaczami Komitetów Obywatelskich i lokalnymi przywódcami NSZZ «Solidarność». Linie podziałów wyglądały rozmaicie w różnych województwach"29.

Nie obyło się również bez konfliktów związanych z równoległym tworzeniem Komitetów Obywatelskich przez skonfliktowane, zwalczające się środowiska i lokalne grupy solidarnościowego podziemia. Zdarzało się nawet, że w regionach powstawały w związku z tym trzy struktury komitetowe. Do sporów w kwestii ich personalnego kształtu oraz list kandydatów do parlamentu doszło między innymi w Białymstoku, Bydgoszczy, Koninie, Łodzi, Płocku, Piotrkowie, Radomiu i Suwałkach ${ }^{30}$. Były

28. „Informator Wyborczy Solidarność Bolesławiec” z 17 kwietnia 1989 (zob. M. Olczak, Ł. Sołtysik, Zarys dziejów Niezależnego Samorząnego Związku Zawodowego "Solidarność" w Bolesławcu, Bolesławiec 2011, s. 254).

29. K. Koseła, Atuty użyteczne w promowaniu aktywności w sferze publicznej w czasach kryzysu systemów znaczeniowych - epizod w historii, [w:] K. Koseła, Polak i katolik. Spętana tożsamość, Warszawa 2003, s. 187-188.

30. A. Dudek, Reglamentowana rewolucja, s. 283. Podziały te wynikały z antagonizmów personalnych czy różnic politycznych, ale bywały również efektem dezintegracyjnej działalności Służby Bezpieczeństwa (ibidem). Na temat sporów dotyczących kandydatów w Bydgoszczy zob. K. Osiński, NSZZ "Solidarność" Region Bydgoski, [w:] NSZZ "Solidarność" 1980-1989, t. 3: Polska Pólnocna, red. Ł. Kamiński, G. Waligóra, Warszawa 2010, s. 470-471. 0 perturbacjach w Koninie zob. M. Przybysz, NSZZ "Solidarność" Region Ziemia Piotrkowska, [w:] NSZZ "Solidarność" 1980-1989, t. 4: Polska Zachodnia, red. Ł. Kamiński, G. Waligóra, Warszawa 2010, s. 620-621. 0 problemach w Łodzi zob. L. Próchniak, NSZZ "Solidarność" Region Ziemia Łódzka, [w:] NSZZ "Solidarność" 1980-1989, t. 4, s. 234. 0 rozbieżnościach w Suwałkach zob. M. Zwolski, NSZZ "Solidarność" Region Pojezierze, [w:] NSZZ "Solidarność" 1980-1989, t. 5: Polska Środkowo-Wschodnia, red. Ł. Kamiński, G. Waligóra, Warszawa 2010, s. 485. Na temat Radomia zob. M. Wierzbicki, NSZZ "Solidarność" Region Ziemia Radomska, [w:] NSZZ "Solidarność" 1980-1989, t. 5, s. 156. 
one zazwyczaj rozstrzygane przez liderów Komitetu Obywatelskiego lub pozostałych członków zespołu ds. koordynacji listy kandydatów i ds. organizacji, który - podobnie jak zespół ds. koordynacji listy kandydatów - utworzono 8 kwietnia 1989 roku ${ }^{31}$. Było to o tyle łatwiejsze, że - jak stwierdzały władze PRL, a konkretnie Komitet Centralny Polskiej Zjednoczonej Partii Robotniczej - widoczne było "duże zdyscyplinowanie i podporządkowanie centrali". W ich ocenie proces wyłaniania kandydatów strony solidarnościowej miał być „ściśle kontrolowany przez opozycyjne centrum", a nawet „w niektórych fragmentach" miało występować "ręczne sterowanie" ${ }^{\prime 32}$.

Rzeczywiście liderzy Komitetu Obywatelskiego "Solidarność" próbowali wpływać na decyzje podejmowane $\mathrm{w}$ terenie, $\mathrm{z}$ różnym zresztą skutkiem, na przykład w Białymstoku Jacek Kuroń, z którym konsultowano tamtejsze kandydatury na posłów i senatorów, zasugerował oddanie dwóch miejsc powstałemu tam w lutym 1989 roku Klubowi Białoruskiemu. Wywołało to jednak "ostry sprzeciw" lokalnych działaczy i w efekcie kandydaci białoruscy wystartowali z niezależnego Białoruskiego Komitetu Wyborczego $0^{33}$. Warto w tym miejscu przypomnieć, że pewien - oczywiście nieformalny - wpływ na dobór kandydatów do parlamentu miał też Kościół, który bardzo mocno wspierał stronę solidarnościową w wyborach czerwcowych, często zresztą pełniąc funkcję mediatora w lokalnych sporach. Tak było na przykład w Skierniewicach, gdzie Kościół miał wręcz "utracić" kandydaturę przedstawiciela NSZZ Rolników Indywidualnych "Solidarność" Edwarda Małeckiego ${ }^{34}$. Odwrotnie było w przypadku Tadeusza Mazowieckiego. Jego kandydaturę na senatora $\mathrm{z}$ województwa płockiego zaproponował biskup Zygmunt Kamiński, a poparli go księża Tadeusz Łebkowski i Józef Kraszewski, 12 kwietnia 1989 roku biorący udział w zebraniu Międzyzakładowego Komitetu Organizacyjnego NSZZ "Solidarność”, na którym wyłaniano kandydatów Komitetu Obywatelskiego ${ }^{35}$. Jeszcze inny był casus Gabrieli Cwojdzińskiej, która została senatorem z województwa koszalińskiego. Była po operacji biodra we Włoszech, kiedy dotarła do niej informacja, że miejscowi działacze Solidarności chcą, aby wystartowała w wyborach. Wśród argumentów za pojawił się również ten, przekazany telefonicznie przez jej męża: „Kościół popiera twoją kandydaturę i biskup prosi"36.

W ocenie Andrzeja Wielowieyskiego 80-90\% decyzji dotyczących kandydatów, które podjęto w województwach, zostało zaakceptowanych w Warszawie $^{37}$. Podobna była ocena Bronisława Geremka, według którego $\mathrm{z}$ warszawskiego nadania miało pochodzić $10-15 \%$ kandydatów ${ }^{38}$. 0znacza to, że decyzje negatywne na wyższym szczeblu należały do rzadkości, w zdecydowanej większości kandydatury regionalne zatwierdzano. Przykładowo w sto-

31. W skład zespołu ds. organizacji weszli: Artur Balazs, Jacek Kuroń, Andrzej Wielowieyski i Henryk Wujec (Dokumenty Komitetu Obywatelskiego. Uchwała, "Tygodnik Mazowsze” 1989, nr 290, s. 1).

32. A. Dudek, Reglamentowana rewolucja, s. 283.

33. T. Danilecki, NSZZ "Solidarność" i opozycja demokratyczna w województwie białostockim u schyłku lat osiemdziesiątych XX w., [w:] Między systemami. Społeczeństwo Polski północno-wschodniej wobec przemian ustrojowych 1989 roku. Studia i materiały, red. M. Markiewicz, A. Pyżewska, Białystok 2014, s. 67.

34. Zob. Raport Krzysztofa Snopińskiego, łącznika z Komitetem Obywatelskim woj. skierniewickiego z dnia 26 kwietnia 1989 r., [w:] Wybory 1989. Dokumenty strony solidarnościowo-opozycyjnej, t. 2: Regiony, red. I. Słodkowska, Warszawa 2011 , s. 217. W ocenie Snopińskiego była to "przykra sprawa” (ibidem, s. 215).

35. J. Pawłowicz, NSZZ „Solidarność" Organizacja Regionu Płockiego, [w:] NSZZ "Solidarność" 1980-1989, t. 5, s. 431. Mazowiecki nie wyraził jednak zgody na kandydowanie.

36. Łączyła nas chęć rozwoju Polski. Wspomnienia senatorów pierwszej kadencji, Warszawa 2014, s. 76.

37. Wypowiedź Andrzeja Wielowieyskiego podczas dyskusji byłych członków OKP w ramach konferencji „Obywatelski Klub Parlamentarny 25 lat później" z 8 listopada 2014 roku.

38. Rok 1989. Geremek odpowiada, Żakowski pyta, Warszawa 2008, s. 168. 
licy odrzucono kandydaturę Eugeniusza Matyjasa, zgłoszoną przez Leszno. Byłemu przewodniczącemu Zarządu Regionu Leszczyńskiego i członkowi Komisji Krajowej NSZZ "Solidarność” z 1981 roku zarzucano bowiem "niesłuszne zachowanie czy postępowanie i występowanie w środkach masowego przekazu w początkach stanu wojennego, a także brak kontaktu i chęci współpracy z Krajową Komisją Wykonawczą" ${ }^{\prime 2}$. Ten pierwszy zarzut był z pewnością przynajmniej po części uzasadniony - Matyjas na początku internowania wydał oświadczenie (odczytane między innymi w „Dzienniku Telewizyjnym”), w którym wzywał działaczy Solidarności do niepodejmowania działań sprzecznych z prawodawstwem stanu wojennego ${ }^{40}$. Jednak jego działalność po odzyskaniu wolności (zwolniono go $\mathrm{z}$ internowania w kwietniu 1982 roku) zdecydowanie przemawia na jego korzyść - między innymi stał na czele Tymczasowego Zarządu Regionu, w grudniu 1982 roku aresztowano go, a następnie w kwietniu 1983 skazano na dwa lata więzienia w zawieszeniu na cztery lata z powodu działalności podziemnej, był też wielokrotnie zatrzymywany i przesłuchiwany, a w latach 1983-1986 pozostawał bez stałego zatrudnienia ${ }^{41}$. Trudniej odnieść się do drugiego $\mathrm{z}$ tych zarzutów - być może chodziło o jego współpracę z Solidarnością Walczącą, co zresztą nie przeszkodziło mu w 1989 roku ponownie zostać przewodniczącym Zarządu Regionu Leszczyńskiego NSZZ "Solidarność". W każdym razie reprezentanci KO podczas burzliwego spotkania w Lesznie 24 kwietnia tego zarzutu już nie powtórzyli² ${ }^{42}$ Innym zdyskwali- fikowanym przez Warszawę kandydatem był znany działacz katolicki Janusz Zabłocki, zgłoszony przez Wojewódzki Komitet Obywatelski w Suwałkach do startu w wyborach do sejmu. Powodem decyzji komisji kwalifikacyjno-kandydackiej była - jak stwierdzono - "przeszłość i charakter zaangażowania politycznego pana Janusza Zabłockiego" ${ }^{43}$.

Funkcjonowała również tak zwana obywatelska lista krajowa. Znalazły się na niej znane osoby (przede wszystkim członkowie Komitetu Obywatelskiego) z Warszawy i innych dużych miast. Były one zgłaszane komitetom regionalnym i wojewódzkim, które miały wprowadzać je na swoje listy. Powodowało to skrajne reakcje - od przyjmowania kandydatur ze stolicy bez dyskusji po zdecydowane ich odrzucenie ${ }^{44}$. Czasem zresztą problemem nie był "desant" ze stolicy, ale sam kandydat. Przykładowo w województwie zielonogórskim chciano wystawić Bronisława Geremka w wyborach do senatu, a gdy okazało się, że będzie on kandydować w innym województwie, proszono o "przydzielenie" Tadeusza Mazowieckiego. Warszawa natomiast proponowała Sławomira Siwka ${ }^{45}$. Ponieważ nie udało się uzgodnić nazwiska kandydata "z Warszawy”, ostatecznie zielonogórskie miało wyłącznie kandydatów lokalnych. Ten niewielki wpływ kierownictwa Komitetu Obywatelskiego dostrzegała również Służba Bezpieczeństwa. Jak 17 kwietnia 1989 roku informowali funkcjonariusze $\mathrm{SB}$, omawiając opinie ze środowiska byłych działaczy Komitetu Obrony Robotników: „proces kompletowania list kandydackich - zarówno do sejmu, jak i senatu

39. Posiedzenia Komitetu Obywatelskiego „Solidarność”, 23 kwietnia 1989 roku, Audytorium Maximum Uniwersytetu Warszawskiego, [w:] Komitet Obywatelski przy Przewodniczacym..., s. 290.

40. W. Handke, NSZZ "Solidarność" Region Leszczyński, [w:] NSZZ "Solidarność" 1980-1989, t. 4, s. 477.

41. M. Zarzycki, M. Łątkowska, Matyjas Eugeniusz, [w:] Encyklopedia Solidarności. Opozycja w PRL 1976-1989, t. 1, Warszawa 2010, s. 271-272.

42. W. Handke, NSZZ "Solidarność" Region Leszczyński..., s. 488. W trakcie spotkania z 24 kwietnia 1989 roku Matyjas zrezygnował $\mathrm{z}$ kandydowania.

43. Posiedzenia Komitetu Obywatelskiego „Solidarność”, 23 kwietnia 1989 roku, Audytorium Maximum Uniwersytetu Warszawskiego, [w:] Komitet Obywatelski przy Przewodniczacym..., s. 300.

44. I. Słodkowska, Komitety Obywatelskie..., s. 89.

45. Posiedzenia Komitetu Obywatelskiego „Solidarność”, 23 kwietnia 1989 roku, Audytorium Maximum Uniwersytetu Warszawskiego, [w:] Komitet Obywatelski przy Przewodniczacym..., s. 295-296. 
- odbywa się oddolnie i uniemożliwia skuteczne i precyzyjne umieszczanie na nich działaczy grupy solidarnościowo-opozycyjnej, którzy byliby w pełni dyspozycyjni wobec [Lecha] Wałęsy i działających przy nim doradców" ${ }^{\prime 46}$. Niespełna dwa tygodnie później - 28 kwietnia - Służba Bezpieczeństwa podawała konkretne przykłady "kandydatów w pełni dyspozycyjnych" (oczywiście w ocenie esbeków) wobec przewodniczącego Solidarności, którym nie udało się uzyskać akceptacji w terenie. Byli to: Maja Komorowska, na której kandydaturę z województwa ostrołęckiego nie zgodzili się miejscowi działacze, oraz Andrzej Szczypiorski, który miał startować w Sieradzu, a ostatecznie został kandydatem na senatora, a potem senatorem $z$ Krosna ${ }^{47}$.

Listę kandydatów Komitetu Obywatelskiego "Solidarność" ułożono w zasadzie już przed 20 kwietnia 1989 roku. Od tej reguły zdarzały się jednak wyjątki. Na przykład w Koszalinie proces wyłaniania kandydatów zakończono 21 kwietnia, ale przegłosowana przez Wojewódzki Komitet Obywatelski lista wywołała konflikt z Międzyzakładowym Komitetem Organizacyjnym w Koszalinie i Tymczasowym Zarządem Regionu NSZZ "Solidarność" Koszalin - Słupsk. Nie pomogły interwencje ani KKW, ani też K0 "Solidarność". W tej sytuacji 22 kwietnia decyzję podjął osobiście Lech Wałęsa, który spotkał się z przedstawicielami zwaśnionych stron (wycofano kandydaturę mecenasa Tadeusza de Viriona $)^{48}$. Ostatnim krokiem było zatwier- dzenie listy 150 kandydatów na posłów oraz 94 na senatorów przez Komitet Obywatelski w dniu 23 kwietnia. Trwało to zresztą kilka godzin, gdyż wiele szczegółów wymagało wyjaśnień - zwłaszcza że większość kandydatów stanowiły osoby znane jedynie w swoim regionie ${ }^{49}$. Wcześniej odbyło się jeszcze kilkugodzinne posiedzenie komisji ds. koordynacji listy kandydatów (w nocy z 22 na 23 kwietnia). W debacie określanej mianem "profesorskiej" brali udział: Bronisław Geremek, Jerzy Kłoczowski, Jan Lityński, Henryk Samsonowicz, Andrzej Stelmachowski, Stanisław Stomma, Andrzej Wielowieyski, Henryk Wujec i Józef Ślisz. W zapisie tego posiedzenia przytaczane były również pojedyncze opinie Zbigniewa Bujaka, Andrzeja Celińskiego i Władysława Frasyniuka ${ }^{50}$.

To nie był jednak koniec prac nad listą kandydatów strony solidarnościowej. Komitet Obywatelski w przyjętej 23 kwietnia uchwale stwierdzał, że „przyjmuje i przedkłada Przewodniczącemu NSZZ «Solidarność» Lechowi Wałęsie" tę listę do akceptacji, co było zresztą czystą formalnością. K0 zobowiązał też Wojewódzkie Komitety Obywatelskie w Nowym Sączu i Skierniewicach do „ponownego rozpatrzenia list kandydatów, zgodnie z sugestiami na zebraniu Komitetu Obywatelskiego "Solidarność»" i przedstawienie ich do 26 kwietnia. Wezwał także do uzgodnienia kandydatury na nieobsadzone miejsce we Włocławku, w ciągu dwóch dni ${ }^{51}$. W kolejnych dniach do obsadzenia pozostało jeszcze jedenaście

46. Załącznik do Informacji Dziennej z dnia 17 kwietnia 1989 r. dot. opinii środowiska postkorowskiego na temat aktualnej sytuacji w kraju, [w:] Zmierzch dyktatury. Polska lat 1986-1989 w świetle dokumentów, t. 1: Lipiec 1986 - maj 1989, oprac. A. Dudek, Warszawa 2013, s. 448.

47. Załącznik do Informacji Dziennej z dnia 28 kwietnia 1989 r. dot. udziału środowisk twórczych w kampanii wyborczej do Sejmu i Senatu PRL, [w:] Zmierzch dyktatury, t. 1, s. 481.

48. I. Słodkowska, Komitety Obywatelskie..., s. 191-192. Ostateczna listę koszalińską dzień później zamknięto na forum K0 "Solidarność" - zamiast de Viriona znalazł się na niej Bogusław Pałka.

49. A. Friszke, Geneza i historia..., s. 62. Zob. też Posiedzenia Komitetu Obywatelskiego "Solidarność”, 23 kwietnia 1989 roku, Audytorium Maximum Uniwersytetu Warszawskiego, [w:] Komitet Obywatelski przy Przewodniczacym..., s. 258-261, 275-305.

50. I. Słodkowska, Komitety Obywatelskie..., s. 92.

51. Uchwała w sprawie listy kandydatów Komitetu Obywatelskiego „Solidarność" z 23 kwietnia 1989 r., [w:] Wybory 1989. Dokumenty strony solidarnościowo-opozycyjnej, t. 1: Kwatera główna, red. I. Słodkowska, Warszawa 2009, s. 151. W przypadku Skierniewic spór dotyczył Edwarda Małeckiego, a w przypadku Nowego Sącza chodziło o uwzględnienie reprezentanta górali przez Wojewódzki Komitet Obywatelski. 
miejsc na liście do sejmu oraz pięć do senatu. Do tego potrzebne okazały się spotkania przedstawicieli centrali z lokalnymi komitetami obywatelskimi, między innymi w Łomży, Piotrkowie Trybunalskim, Rzeszowie, Skierniewicach czy Włocławku ${ }^{52}$.

$\mathrm{Na}$ listach Komitetu Obywatelskiego zabrakło wielu znanych działaczy Solidarności. Niektórzy - jak Tadeusz Mazowiecki, Jan Olszewski czy Aleksander Hall - zrezygnowali w proteście przeciw odrzuceniu ich koncepcji poszerzenia zaplecza KO. Inni natomiast - Bogdan Borusewicz, Zbigniew Bujak czy Władysław Frasyniuk - uznali, przynajmniej oficjalnie, pracę w związku za ważniejszą niż w parlamencie ${ }^{53}$. To było jednak jedynie oficjalne uzasadnienie, nie zawsze zresztą zgodne $\mathrm{z}$ prawdą. Jak relacjonował po latach Bujak: „Nie kandydowałem ja, nie kandydował Władek Frasyniuk i oczywiście dzisiaj nie mam wątpliwości, że zrobiliśmy błąd, chociaż uważaliśmy wtedy, że nasza kalkulacja jest poprawna. 0 tym, że nie kandydujemy zdecydowaliśmy się w momencie, w którym także Lech Wałęsa powiedział: «Nie, ja nie kandyduję». Uznaliśmy, że jeżeli Lech mówi, że nie kandyduje, tzn. że coś się kroi, nie wiemy jeszcze co, ale coś się kroi. No co? Wiedzieliśmy, że Lech Wałęsa w różnych momentach gotów jest wystawiać ludzi, ale jak coś idzie nie tak, to można ich spisywać na straty, poddawać krytyce. Okazuje się, że on wycofuje się do swojego Sulejówka, ale po to, żeby w odpowiednim momencie skrytykować. No dobrze, tylko że taka krytyka klubu parlamentarnego mogła być bardzo groźna. Kto w takim razie mógłby w tym momencie stawać w obronie tego klubu? Oczywiście najważniejsze jest to co o tych ludziach, a jeśli będzie rząd solidarnościowy, to o rządzie, najważniejsze jest to, co mówi «Solidarność». W związku z tym uznaliśmy z Władkiem Frasyniukiem, że nasze miejsce jest $\mathrm{w}$ «Solidarności». Można powiedzieć, że mieliśmy rację, bo naprawdę bardzo szybko się pojawiły ataki na Tadeusza Mazowieckiego, na klub parlamentarny [0KP]. I my naprawdę musieliśmy ich bronić, naprawdę występowaliśmy, i w radio, i w telewizji przy różnych okazjach, i musieliśmy ten klub parlamentarny, i samego Tadeusza brać w obronę"54.

Nie kandydował również - o czym była przed chwilą mowa - Lech Wałęsa. Ewidentnie obawiał się porażki. Nie tyle zresztą wyborczej, co powyborczej, wynikającej ze współodpowiedzialności parlamentarzystów za rozwiązywanie bolączek Polski i Polaków. Jak stwierdzał 8 kwietnia podczas posiedzenia Komitetu Obywatelskiego "Solidarność": „Możemy nie zdążyć rozwiązać problemów ekonomicznych i odium spadnie na was, na naszych senatorów. Wy przegracie, a ja będę czysty. Musi być ktoś w odwodzie, by mógł ratować was i kraj"55. W tym postanowieniu (podobnie jak inni, wymienieni wcześniej działacze) pozostał konsekwentny. Warto w tym miejscu przypomnieć, że podczas posiedzenia K0 z 23 kwietnia Adam Michnik proponował nawet: „Żeby zobowiązać Przewodniczącego i wszystkich ludzi przez niego wyznaczonych do startowania w wyborach", i krótko uzasadniak: „bo musimy wybory wygrać, a nie przegrać" ${ }^{\prime 56}$. Takiej uchwały oczywiście nie przyjęto. Skończyło się jedynie na deklaracji przewodniczącego Solidarności: "Ja nie uchylam się od żadnej odpowiedzialności. Będę biegł przed każdym senatorem i posłem. Będę go zastępował i uzupełnial" ${ }^{\prime 57}$.

52. W Łomży odbyło się ono 25 kwietnia, jego przebieg krótko opisuje Inka Słodkowska. Zob. I. Słodkowska, Komitety Obywatelskie..., s. 93.

53. Ibidem, s. 287.

54. Niespodzianka $1989 . . .$, s. 26-27.

55. A. Friszke, Geneza i historia..., s. 62.

56. Posiedzenia Komitetu Obywatelskiego "Solidarność”, 23 kwietnia 1989 roku, Audytorium Maximum Uniwersytetu Warszawskiego, [w:] Komitet Obywatelski przy Przewodniczacym..., s. 263.

57. Ibidem. Warto w tym miejscu przytoczyć jego opinię na temat kandydatów strony solidarnościowej: „Wszystkich tych skazańców, których daliśmy do sejmu, wszystkich tych skazańców, których daliśmy do senatu... To jest kwiat, który musi zrobić fundament pod przyszłą Polskę" (ibidem). 
I rzeczywiście w kampanii wyborczej Wałęsa był obecny, a nawet bardzo obecny. Znakiem firmowym kandydatów Komitetu Obywatelskiego "Solidarność" stało się bowiem zdjęcie z przewodniczącym Solidarności. Ta kwestia zresztą obrosła legendą. Rzekomo jedyny kandydat Komitetu Obywatelskiego, który przepadł w wyborach (Piotr Baumgart), miał być równocześnie jedynym, który nie miał plakatu z Lechem Wałęsą. W rzeczywistości jednak takich osób było zdecydowanie więcej. Jak wynika z badań Adama Cherka, było ich aż $23^{58}$. Co więcej, nie było wśród nich Baumgarta. W ocenie Antoniego Dudka wspólne zdjęcie kandydatów Komitetu Obywatelskiego z przewodniczącym Solidarności "0kazało się [...] propagandowym majstersztykiem: powszechnie znany wizerunek popularnego Wałęsy, wzmacniał w oczach wyborców wiarygodność poszczególnych kandydatów, z których zdecydowana większość nie miała wcześniej szans na zaistnienie w społecznej świadomości. Dodatkowo kreował szczególnie nośny: mit spójnej i solidarnej «drużyny Lecha», wyraźnie odcinającej się od silnie zdezintegrowanego obozu władzy"59.
Posłowie K0, którzy otrzymali największą (procentowo) liczbę głosów ${ }^{60}$

\begin{tabular}{|l|l|}
\hline Imię i nazwisko & Wynik 4 czerwca 1989 \\
\hline Mieczysław Gil & $89,30 \%$ \\
\hline Jerzy Zdrada & $86,66 \%$ \\
\hline Jacek Merkel & $86,59 \%$ \\
\hline Stanisław Padykuła & $86,24 \%$ \\
\hline Władysław Liwak & $86,12 \%$ \\
\hline Józefa Hennelowa & $84,58 \%$ \\
\hline Józef Orzeł & $84,56 \%$ \\
\hline Jacek Bujak & $83,73 \%$ \\
\hline Tadeusz Trelka & $83,73 \%$ \\
\hline Kazimierz Rostek & $83,72 \%$ \\
\hline
\end{tabular}

\section{Posłowie K0, którzy otrzymali najmniejszą (pro- centowo) liczbę głosów}

\begin{tabular}{|l|l|l|}
\hline Imię i nazwisko & $\begin{array}{l}\text { Wynik } \\
\text { 4 czerwca } \\
\mathbf{1 9 8 9}\end{array}$ & $\begin{array}{l}\text { Wynik } \\
\mathbf{1 8} \text { czerwca } \\
\mathbf{1 9 8 9}\end{array}$ \\
\hline Andrzej Wybrański & $41,33 \%$ & $55,62 \%$ \\
\hline Marek Jurek & $52,86 \%$ & - \\
\hline Wiesław Kowalski & $53,26 \%$ & - \\
\hline Józef Lubieniecki & $53,31 \%$ & - \\
\hline Adela Dankowska & $54,33 \%$ & - \\
\hline Kazimierz Błaszczyk & $54,72 \%$ & - \\
\hline Marek Rusakiewicz & $55,11 \%$ & - \\
\hline Wiesław Zajączkowski & $55,96 \%$ & - \\
\hline Zenon Złakowski & $56,04 \%$ & - \\
\hline Bohdan Kopczyński & $56,22 \%$ & - \\
\hline
\end{tabular}

58. Z różnych przyczyn plakatu z Lechem Wałęsą nie mieli: Janusz Byliński, Roman Ciesielski, Gabriela Cwojdzińska, Krzysztof Dowgiałło, Lech Kaczyński, Olga Krzyżanowska, Wiktor Kulerski, Bogdan Lis, Jacek Merkel, Czesław Nowak, Witold Trzeciakowski, Eugeniusz Ujas, Eugeniusz Wilkowski i Stanisław Żak (nie wzięli udziału w sesji zdjęciowej z przewodniczącym Solidarności, a także: Zbigniew Bobak, Michał Chałoński, Antoni Furtak, Ignacy Guenther, Adam Mitura, Edward Rzepka, Jerzy Stępień, Maria Stolzman i Andrzej Wybrański (mimo udziału w sesji, w wyniku pomyłek i bałaganu). Więcej na ten temat zob. A. Cherek, Plakaty wyborcze kandydatów Komitetu Obywatelskiego z Lechem Wałęsq, "Krakowskie Studia Małopolskie” 2013, nr 18, s. 384-410, http://www.google.pl/url?url=http://www.new.archiwaprzelomu.pl/download/1/type/dysputy\&rct=j\&frm=1\&q=\& esrc=s\&sa=U\&ei=741nVNv8F4nZPcq9gMAH\&ved=0CCYQFjAC\&usg=AF0jCNEREWiFCBlMltyDZQQ9MldGGp70iA (dostęp: 11.11.2020).

59. A. Dudek, Reglamentowana rewolucja..., s. 287.

60. Tu i dalej dane na podstawie: Nasi $w$ Sejmie... 


\section{Senatorowie K0, którzy otrzymali największą (procentowo) liczbę głosów}

\begin{tabular}{|l|l|}
\hline Imię i nazwisko & Wynik 4 czerwca 1989 \\
\hline Zofia Kuratowska & $82,47 \%$ \\
\hline Józef Ślisz & $81,31 \%$ \\
\hline Roman Ciesielski & $81,24 \%$ \\
\hline Bolesław Fleszar & $79,37 \%$ \\
\hline Wiesław Lipko & $77,94 \%$ \\
\hline Tadeusz Ulma & $77,77 \%$ \\
\hline Stanisław Chrobak & $76,94 \%$ \\
\hline Gustaw Holoubek & $75,64 \%$ \\
\hline Karol Modzelewski & $74,95 \%$ \\
\hline Zbigniew Romaszewski & $74,91 \%$ \\
\hline
\end{tabular}

\section{Senatorowie K0, którzy otrzymali najmniejszą} (procentowo) liczbę głosów

\begin{tabular}{|l|l|l|}
\hline Imię i nazwisko & $\begin{array}{l}\text { Wynik } \\
\text { 4 czerwca } \\
\mathbf{1 9 8 9}\end{array}$ & $\begin{array}{l}\text { Wynik } \\
\mathbf{1 8} \text { czerwca } \\
\mathbf{1 9 8 9}\end{array}$ \\
\hline Zdzisław Nowicki & $36,36 \%$ & $50,09 \%$ \\
\hline Antoni Żurawski & $41,30 \%$ & $61,81 \%$ \\
\hline Henryk Grządzielski & $41,31 \%$ & $61,70 \%$ \\
\hline Aleksander Paszyński & $44,66 \%$ & $63,08 \%$ \\
\hline Stanisław Hoffmann & $46,02 \%$ & $63,75 \%$ \\
\hline Cezary Józefiak & $47,37 \%$ & $58,53 \%$ \\
\hline Jan Józef Lipski & $47,67 \%$ & $67,65 \%$ \\
\hline Walerian Piotrowski & $52,87 \%$ & - \\
\hline $\begin{array}{l}\text { Antoni } \\
\text { Jutrzenka-Trzebiatowski }\end{array}$ & $53,66 \%$ & - \\
\hline Gabriela Cwojdzińska & $53,77 \%$ & - \\
\hline
\end{tabular}

Trudno powiedzieć, jak duże przełożenie na wynik głosowania miał wspólny plakat kandydata z przewodniczącym Solidarności. Oczywiste jest jednak, że zwiększał on jego szanse wyborcze. Tym bardziej że - jak podkreśla na przykład Paweł Siedziako lokalni kandydaci $\mathrm{KO}$ w większości nie byli szerzej znani. W ich przypadku zdjęcie z Wałęsą ułatwiało więc polityczną identyfikację $e^{61}$ W każdym razie, jeśli przyjrzeć się dziesięciu najgorszym wynikom (procentowym) w "drużynie Lecha", to okaże się, że spośród osób nieposiadających plakatu z Lechem Wałęsą w gronie tym znalazky się trzy osoby, w tym Andrzej Wybrański - jedyny kandydat na posła, który dostał się do sejmu w drugiej turze wyborów (dostał jedynie 41,33\% ważnych głosów). Z drugiej strony w grupie tych, którzy w wyborach czerwcowych dostali procentowo najwięcej głosów, znalazły się dwie inne osoby niewykorzystujące w kampanii plakatu z przewodniczącym Solidarności - Roman Ciesielski i Jacek Merkel. Ciesielski w wyborach do senatu osiągnął trzeci wynik wśród kandydatów Komitetu Obywatelskiego (81,24\% głosów). Analogiczne miejsce wśród kandydatów Komitetu Obywatelskiego do sejmu zajął Merkel (86,59\% głosów). Na marginesie można wspomnieć, że w gronie ośmiu kandydatów, którzy w pierwszej turze nie osiągnęli wyniku gwarantującego wybór do senatu, nie było ani jednej osoby niewykorzystującej w kampanii plakatu z Wałęsą. W tym miejscu warto też porównać wyniki braci Lecha i Jarosława Kaczyńskich w wyborach do senatu. Pierwszy z nich, startując bez plakatu, w województwie gdańskim „kolebce Solidarności" - otrzymał 67,76\% głosów, podczas gdy jego brat bliźniak, dysponujący co prawda wspomnianym plakatem, ale kandydujący w zdecydowanie trudniejszym województwie elbląskim, 57,98\% głosów. Prowadzi to do wniosku, że na wynik wyborczy danego kandydata wpływ miało nie tylko owo mityczne już zdjęcie z Lechem Wałęsą, ale również inne czynniki, na przykład miejsce kandydowania (na terenach zamieszkanych przez mniejszości narodowe kandydaci K0 otrzymywali znacznie mniej głosów niż w innych częściach kraju) czy kontrkandydaci - i to nie tylko ci ze strony partyjno-państwowej, ale też osoby związane z opozycją lub działające w niej, lecz startujące samodzielnie, spoza list Komitetu Obywatelskiego ${ }^{62}$.

61. P. Siedziako, Bez wyboru..., s. 336 .

62. Bardzo trudnego kontrkandydata miał na przykład Jacek Kuroń - był nim Władysław Siła-Nowicki. 
Obywatelski Klub Parlamentarny ukonstytuował się 23 czerwca 1989 roku podczas pierwszego wspólnego posiedzenia posłów i senatorów wybranych z listy Solidarności, które odbyło się na Uniwersytecie Warszawskim. Początkowo zrzeszał 161 posłów i 98 senatorów wybranych w wyborach czerwcowych $^{63}$. Z czasem jednak uległ podziałowi na partie polityczne. W listopadzie $1990 \mathrm{w}$ drugiej turze wyborów prezydenckich 0KP poparł Lecha Wałęsę. W rezultacie w styczniu 1991 z klubu wystąpiła grupa posłów popierająca w wyborach prezydenckich Tadeusza Mazowieckiego (45 posłów i 29 senatorów). Utworzyli oni Klub Parlamentarny Unii Demokratycznej. Był to jednak dopiero początek rozpadu Obywatelskiego Klubu Parlamentarnego. I tak na przykład po kolejnych dwóch miesiącach z OKP wystąpiła grupa "Solidarność" Pracy. W efekcie, kiedy klub ten kończył działalność, czyli 25 października 1991 roku, w dniu rozwiązania Sejmu PRL X kadencji, liczył już tylko 170 członków (105 posłów oraz 65 senatorów) ${ }^{64}$.

Pierwszym przewodniczącym Obywatelskiego Klubu Parlamentarnego został Bronisław Geremek (pod koniec 1990 roku jego miejsce zajął Mieczysław Gil), pierwszym wiceprzewodniczącym Andrzej Wielowieyski, wiceprzewodniczącymi: Gabriel Janowski, Paweł Łączkowski, Jan Maria Rokita i Janusz Ziółkowski, a sekretarzami: Andrzej Celiński oraz Henryk Wujec. Ponadto członkami Prezydium byli: Antoni Furtak, Olga Krzyżanowska, Zofia Kuratowska, Janusz Steinhoff, Hanna Suchocka, Andrzej Stelmachowski, Józef Ślisz i Edward Wende. Warto zauważyć, że chociaż żadna z kobiet nie weszła w skład kierownictwa tego gremium, to ich odsetek (niespełna 19\%) w Prezydium 0KP był wyższy niż w samym Obywatelskim Klubie Parlamentarnym $(8,5 \%)^{65}$. Tak na marginesie - wszystkie 22 kobiety weszły do sejmu i senatu w pierwszej turze.

Powszechnie uważa się, że posłami i senatorami Obywatelskiego Klubu Parlamentarnego zostały osoby bez doświadczenia parlamentarnego. Jeśli patrzeć na to od strony formalnej, to rzeczywiście tak było - senator Ryszard Reiff, będący posłem na sejm PRL w latach 1965-1969 oraz 1980-1985 (reprezentował PAX), czy Hanna Suchocka, posłanka Stronnictwa Demokratycznego w latach 1980-1985, należeli bowiem do wyjątków. Jednak doświadczenie parlamentarne, a właściwie quasi-parlamentarne, miało zdecydowanie więcej członków 0KP. Spośród posłów i senatorów tego klubu 51 (39 posłów i 12 senatorów) było delegatami na I Krajowy Zjazd Delegatów NSZZ "Solidarność" we wrześniu i październiku 1981 roku, który był wyjątkową w PRL lekcją demokracji. Do grona tego należeli między innymi Jan Józef Lipski, Bogdan Lis i Karol Modzelewski (spośród późniejszych senatorów 0KP) czy Ryszard Bugaj, Jerzy Dłużniewski, Aleksander Małachowski, Jacek Merkel i Janusz Onyszkiewicz (z grona przyszłych posłów). Oznacza to, że co piąty parlamentarzysta Obywatelskiego Klubu Parlamentarnego miał za sobą przygodę z nietypowym parlamentaryzmem, jakim był pierwszy zjazd blisko 900 delegatów NSZZ "Solidarność" z roku 1981. Co więcej, część z nich uczestniczyła wcześniej w pracach Krajowej Komisji Porozumiewawczej (Bogdan Lis czy Roman Niegosz) ${ }^{66}$, została wybrana pod-

63. Senatorów było 98, a nie 99, ponieważ zmarł (jeszcze przed złożeniem ślubowania) Grzegorz Białkowski.

64. Byli posłowie i senatorowie OKP na koniec kadencji wchodzili też w skład Klubu Parlamentarnego Unia Demokratyczna, Klubu Parlamentarnego "Solidarności Pracy”, Koła Parlamentarnego PSL i Parlamentarnego Klubu Chrześcijańsko-Ludowego.

65. Na 161 miejsc w Sejmie 16 przypadło paniom. Posłankami zostały: Adela Dankowska, Maria Dmochowska, Józefa Hennelowa, Anna Maria Knysok, Stanisława Krauz, Olga Krzyżanowska, Barbara Labuda, Grażyna Langowska, Elżbieta Seferowicz, Maria Sielicka-Gracka, Grażyna Staniszewska, Maria Stępniak, Maria Stolzman, Hanna Suchocka, Anna Urbanowicz i Teresa Zalewska. Z kolei wśród 99 senatorów znalazło się 6 kobiet (Anna Bogucka-Skowrońska, Gabriela Cwojdzińska, Alicja Grześkowiak, Stefania Hejmanowska, Zofia Kuratowska, Anna Radziwiłł).

66. Nie byli oni jednak - jak się powszechnie podaje - członkami KKP, lecz uczestnikami jej posiedzeń. Formalnie (poza kilkoma wyjątkami) członkami OKP były bowiem nie osoby fizyczne, lecz organizacje międzyzakładowe. 
czas zjazdu do Komisji Krajowej (Mieczysław Gil, Ryszard Iwan, Zbigniew Janas, Józef Jungiewicz, Andrzej Kralczyński, Bogdan Lis, Jacek Merkel, Karol Modzelewski, Janusz Onyszkiewicz, Andrzej Piesiak, Zbigniew Romaszewski, Antoni Tokarczuk i Henryk Wujec), zasiadała we władzach krajowych różnych branż związku (Józef Lubieniecki był wiceprzewodniczącym Krajowej Komisji Koordynacyjnej Pracowników Wymiaru Sprawiedliwości, a Elżbieta Seferowicz członkiem Krajowej Komisji Koordynacyjnej Pracowników Służby Zdrowia) lub też w jego władzach podziemnych (zarówno krajowych, jak i regionalnych, między innymi Jerzy Dłużniewski - w 1984 roku współzałożyciel i przewodniczący Regionalnej Komisji Wykonawczej NSZZ „Solidarność" Ziemia Łódzka, członek Tymczasowej Komisji Koordynacyjnej, od 1987 członek Krajowej Komisji Wykonawczej, i Wiktor Kulerski - w 1982 roku współtwórca Regionalnej Komisji Wykonawczej NSZZ "Solidarność" Regionu Mazowsze, w 1986 członek Tymczasowej Komisji Koordynacyjnej, a od 1986 członek jawnej RKW Mazowsze). Ponadto wśród członków Obywatelskiego Klubu Parlamentarnego znalazło się wielu ekspertów, w tym czołowi doradcy związku (Ryszard Bugaj - doradca Krajowej Komisji Porozumiewawczej (KKP) / Komisji Krajowej (KK), a od 1987 roku Krajowej Komisji Wykonawczej i Lecha Wałęsy, Bronisław Geremek - w sierpniu 1980 roku członek Komisji Ekspertów Międzyzakładowego Komitetu Strajkowego w Gdańsku, doradca Międzyzakładowego Komitetu Założycielskiego NSZZ "Solidarność" w Gdańsku, Krajowej Komisji Porozumiewawczej (KKP) / Komisji Krajowej (KK), od 1983 Tymczasowej Komisji Koordynacyjnej i Lecha Wałęsy, a od 1987 Krajowej Komisji Wykonawczej, czy Lech Kaczyński - w sierpniu 1980 roku doradca Międzyzakładowego Komitetu Strajkowego w Gdańsku, a w latach 1982-1988 członek zespołu doradców Lecha Wałęsy). W zdecydowanej większości tworzyły go jednak po prostu osoby związane z opozycją, zwłaszcza solidarnościową. Byli to przede wszystkim działacze Solidarności (w większości ci z okresu solidarnościowego karnawału), a także (oczywiście już w mniejszym stopniu) ludzie rolniczej Solidarności. Jak stwierdzano w informacji o 0KP, stanowili oni „reprezentację tych sił społecznych, które: w $1980 \mathrm{r}$. powołały pierwszy w krajach socjalistycznych wolny związek zawodowy «Solidarność»; po wprowadzeniu 13 grudnia 1981 roku stanu wojennego i w latach późniejszych opierały się skutecznie jego skutkom; wiosną 1989 roku doprowadziły do Okrągłego Stołu - pierwszych w tej części świata negocjacji władz z przedstawicielami opozycji" ${ }^{\prime 67}$. Zakładano, że $\mathrm{w}$ parlamencie będą reprezentować opozycję. I na początku tak rzeczywiście było. Później jednak wzięli pełną odpowiedzialność za kraj.

Dalsze losy członków Obywatelskiego Klubu Parlamentarnego były różne. W czasie kadencji 1989-1991 zmarł jeden poseł 0KP (Walerian Pańko, który zginął w wypadku samochodowym 7 października 1991), a także aż pięciu senatorów: Grzegorz Białkowski (29 czerwca 1989), Edmund Osmańczyk (4 października 1989), Adam Stanowski (7 lutego 1990), Mieczysław Tarnowski (11 maja 1991) i Jan Józef Lipski (10 września 1991). Po zakończeniu kadencji sejmu kontraktowego i senatu I kadencji część z byłych już posłów i senatorów Obywatelskiego Klubu Parlamentarnego w 1991 roku powróciła do swego zawodu (Jacek Ambroziak, Maciej Bednarkiewicz, Krzysztof Dowgiałło czy Andrzej Łapicki), inni zajęli się biznesem (Jerzy Gil czy Janusz Rożek), przeszli na emeryturę (Kazimierz Błaszczyk, Andrzej Kosmalski, Czesław Kurzajewski, Adam Mitura, Henryk Sienkiewicz). Po wyborach 1991 roku grupa byłych parlamentarzystów OKP znalazła się w nowym parlamencie, oczywiście w różnych klubach - Unii Demokratycznej (Maria Dmochowska, Józefa Hennelowa, Barbara Labuda, Jan Lityński, Janusz Onyszkiewicz czy Henryk Wujec), Polskiego Programu Liberalnego (Andrzej

67. Obywatelski Klub Parlamentarny Polska, [w:] Obywatelski Klub Parlamentarny w wybranych dokumentach Archiwum Senatu, Kancelaria Senatu, Warszawa 2014, s. 17. 
Arendarski, Jan Krzysztof Bielecki, Jacek Merkel, Jan Antoni Rzymełka i Krzysztof Żabiński), Zjednoczenia Chrześcijańsko-Narodowego (Marek Jurek, Jan Łopuszański i Stefan Niesiołowski), Konwencji Polskiej (Artur Balazs, Janusz Steinhoff czy Mieczysław Gil), Porozumienia Ludowego (Antoni Furtak), Solidarności (Edward Müller, Elżbieta Seferowicz), Porozumienia Centrum (Jacek Bujak, Marek Dziubek, Andrzej Kern, Czesław Nowak, Krzysztof Putra, Czesław Sobierajski i Bolesław Twaróg), Ruchu dla Rzeczypospolitej (Roman Bartoszcze, Edmund Krasowski i Stanisław Węgłowski) oraz Koła Unii Pracy
(Ryszard Bugaj i Aleksander Małachowski) ${ }^{68}$. Byli członkowie 0KP zajmowali w późniejszych latach najwyższe stanowiska w państwie - byli prezydentami (Lech Kaczyński, 2005-2010), premierami (Jan Krzysztof Bielecki, 1991, Hanna Suchocka, 1992-1993, czy Jarosław Kaczyński, 2006-2007). Jeszcze inni pełnili funkcje ministerialne. Nadal zresztą wielu członków Obywatelskiego Klubu Parlamentarnego - mimo że przestał on istnieć już ponad 28 lat temu - jest czynnych w polskiej polityce, a niektórzy z nich mają na los naszego kraju duży wpływ.

68. Więcej na ten temat zob. Co się stało z "drużyną Wałęsy", "Gazeta Wyborcza", 3.06.1993. 


\section{Bibliografia}

Cherek A., Plakaty wyborcze kandydatów Komitetu Obywatelskiego z Lechem Wałęsa, "Krakowskie Studia Małopolskie” 2013, nr 18. Co się stało z "drużyną Wałęsy", "Gazeta Wyborcza", 3.06.1993. Codogni P., Wybory czerwcowe 1989 roku. U progu przemiany ustrojowej, Warszawa 2012.

Danilecki T., NSZZ "Solidarność" $i$ opozycja demokratyczna w województwie białostockim u schyłku lat osiemdziesiątych XX w., [w:] Między systemami. Społeczeństwo Polski północno-wschodniej wobec przemian ustrojowych 1989 roku. Studia i materiały, red. M. Markiewicz, A. Pyżewska, Białystok 2014.

Dokumenty Komitetu Obywatelskiego. Uchwała, „Tygodnik Mazowsze" 1989, nr 290.

Dokumenty władz NSZZ "Solidarność" 1981-1989, oprac. J. Olaszek, Warszawa 2010.

Dudek A., Reglamentowana rewolucja. Rozkład dyktatury komunistycznej w Polsce 1988-1990, Kraków 2004.

Gieszczyńska R., Komitet Obywatelski "Solidarność" Regionu Warmińsko-Mazurskiego w wyborach 4 czerwca 1989 roku, [w:] Olsztyński Czerwiec '89, Olsztyn 2009.

Handke W., NSZZ "Solidarność" Region Leszczyński, [w:] NSZZ "Solidarność" 1980-1989, t. 4: Polska Zachodnia, red. Ł. Kamiński, G. Waligóra, Warszawa 2010.

Komitet Obywatelski przy Przewodniczącym NSZZ "Solidarność" Lechu Wałęsie. Stenogramy posiedzeń 7 listopada 1987, 18 grudnia 1988, 23 kwietnia 1989, oprac. M. Strasz, Warszawa 2006. Koseła K., Polak i katolik. Spętana tożsamość, Warszawa 2003. Ligarski S., Komitet Obywatelski NSZZ "Solidarnośc" we Wrocławiu, t. 1, s. 15 (maszynopis w posiadaniu autora).

Ligarski S., Rok 1989 a Solidarność Walcząca, [w:] Solidarność Walcząca 1982-1989. Studia i szkice, red. S. Ligarski, M. Siedziako, Szczecin-Warszawa 2019.

Eączyła nas chęć rozwoju Polski. Wspomnienia senatorów pierwszej kadencji, Warszawa 2014.

Nasi w Sejmie i Senacie. Posłowie i senatorowie wybrani z listy Solidarności", Warszawa 1990.

Niespodzianka 1989, Warszawa 2010.

Obywatelski Klub Parlamentarny w wybranych dokumentach Archiwum Senatu, Kancelaria Senatu, Warszawa 2014.

Olczak M., Sołtysik Ł., Zarys dziejów Niezależnego Samorządnego Związku Zawodowego "Solidarność" w Bolesławcu, Bolesławiec 2011.
Osiński K., NSZZ "Solidarność" Region Bydgoski, [w:] NSZZ "Solidarność" 1980-1989, t. 3: Polska Północna, red. E. Kamiński, G. Waligóra, Warszawa 2010.

Pawłowicz J., NSZZ "Solidarność" Organizacja Regionu Płockiego, [w:] NSZZ "Solidarność" 1980-1989, t. 5: Polska Środkowo-Wschodnia, red. Ł. Kamiński, G. Waligóra, Warszawa 2010. Próchniak L., NSZZ "Solidarność" Region Ziemia Łódzka, [w:] NSZZ "Solidarność" 1980-1989, t. 4: Polska Zachodnia, red. Ł. Kamiński, G. Waligóra, Warszawa 2010.

Przybysz M., NSZZ "Solidarność" Region Ziemia Piotrkowska, [w:] NSZZ "Solidarność" 1980-1989, t. 4: Polska Zachodnia, red. Ł. Kamiński, G. Waligóra, Warszawa 2010.

Siedziako P., Bez wyboru. Głosowania do Sejmu PRL (1952-1989), Warszawa 2018.

Rok 1989. Geremek odpowiada, Żakowski pyta, Warszawa 2008. Słodkowska I., Komitety Obywatelskie 1989-1992. Rdzeń polskiej transformacji, Warszawa 2014.

Wierzbicki M., NSZZ "Solidarność" Region Ziemia Radomska, [w:] NSZZ "Solidarność" 1980-1989, t. 5: Polska Środkowo-Wschodnia, red. Ł. Kamiński, G. Waligóra, Warszawa 2010.

Wybory 1989. Dokumenty strony solidarnościowo-opozycyjnej, t. 1: Kwatera główna, red. I. Słodkowska, Warszawa 2009. Wybory 1989. Dokumenty strony solidarnościowo-opozycyjnej, t. 2: Regiony, red. I. Słodkowska, Warszawa 2011.

Zarzycki M., Łątkowska M., Matyjas Eugeniusz, [w:] Encyklopedia Solidarności. Opozycja w PRL 1976-1989, t. 1, Warszawa 2010. Zmierzch dyktatury. Polska lat 1986-1989 w świetle dokumentów, t. 1: Lipiec 1986 - maj 1989, oprac. A. Dudek, Warszawa 2013. Zwolski M., NSZZ "Solidarność" Region Pojezierze, [w:] NSZZ "Solidarność" 1980-1989, t. 5: Polska Srodkowo-Wschodnia, red. Ł. Kamiński, G. Waligóra, Warszawa 2010.

\section{Abstrakt}

Ze względu na plebiscytowy charakter wyborów z czerwca 1989 roku przyszłych posłów i senatorów opozycyjnego Obywatelskiego Klubu Parlamentarnego de facto wyłoniono w kwietniu tego roku, kiedy zamykano listy wyborcze Komitetu Obywatelskiego. Te swoiste prawybory miały różny przebieg w różnych częściach kraju i nie były wolne od sporów (zarówno na szczeblu regionalnym, jak i na linii "teren"-Warszawa). W wyborach nie wystartowała zresztą część czołowych działaczy opozycji, idąc za przykładem Lecha Wałęsy. Ten ostatni był jednak mocno obecny w kampanii wyborczej osób reprezentujących Komitet Obywatel- 
ski, których wyróżnikiem - w zdecydowanej większości - było wspólne zdjęcie z przewodniczącym Solidarności. Niewątpliwie ta nie zawsze $w$ pełni demokratycznie wyłoniona solidarnościowa drużyna osiągnęła w wyborach sukces, obsadzając niemal wszystkie miejsca w Sejmie i Senacie PRL, które potencjalnie mogła zdobyć. Wybrani do parlamentu przedstawiciele opozycji utworzyli w nim Obywatelski Klub Parlamentarny.

Słowa kluczowe: Solidarność, Komitet Obywatelski, wybory, 1989, posłowie, senatorowie, Obywatelski Klub Parlamentarny

\begin{abstract}
Due to the referendum nature of the elections in June 1989, the future deputies and senators of the opposition Civic Parliamentary Club were actually elected in April that year, when the election lists of the Citizens' Committee were closed. These peculiar primary elections varied in different parts of the country and were not free from disputes (both at the regional level and on the "regional" - Warsaw line). Besides, some of the leading opposition activists did not take part in the elections, following the example of Lech Wałęsa. The latter, however, was strongly present in the election campaign of people representing the Citizens' Committee, whose distinguishing feature - in the vast majority - was a photo taken with the leader of "Solidarity". Undoubtedly, this "Solidarity" team, not always fully democratically elected, achieved success in the elections, filling almost all the seats in the Sejm and Senate of the Polish People's
\end{abstract}

Republic, which it could potentially win. The opposition representatives elected to the parliament formed there the Civic Parliamentary Club.

Keywords: Solidarity, Citizens' Committee, elections, 1989, deputies, senators, Civic Parliamentary Club

Grzegorz Majchrzak (ur. 1969) - historyk, dr, pracownik Instytutu Pamięci Narodowej, członek Stowarzyszenia Archiwum Solidarności i Stowarzyszenia Wolnego Słowa. Autor książek: Kontakt operacyjny "Delegat" vel "Libella" (2009); "Solidarność" na celowniku. Wybrane operacje SB przeciwko związkowi i jego działaczom (2016); Tajemnice stanu wojennego (2016); Smutni panowie na olimpijskim szlaku. Inwigilacja polskich olimpijczyków przez Służbę Bezpieczeństwa (2017); (z S. Ligarskim) Artyści, PRL i bezpieka. Herbert, Miłosz, Hłasko i inni... (2018); (z S. Ligarskim) 1989. Rok przemian (2019).

Grzegorz Majchrzak (b. 1969) holds a PhD in history; he works for the Institute of National Remembrance. Author of books: Kontakt operacyjny "Delegat" vel "Libella" (2009); "Solidarność" na celowniku. Wybrane operacje SB przeciwko zwiąkowi i jego działaczom (2016); Tajemnice stanu wojennego (2016); Smutni panowie na olimpijskim szlaku. Inwigilacja polskich olimpijczyków przez Służbę Bezpieczeństwa (2017); (co-author with S. Ligarski) Artyści, PRL i bezpieka. Herbert, Miłosz, Hłasko i inni... (2018); (co-author with S. Ligarski) 1989. Rok przemian (2019). 